\title{
Article
}

http://dx.doi.org/10.11646/phytotaxa.283.1.4

\section{Synopsis of Himatanthus (Apocynaceae, Rauvolfiodieae: Plumerieae) species from Peru}

\author{
CARLOS A. AMASIFUEN GUERRA ${ }^{1}$, PIERO G. DELPRETE ${ }^{2 *} \&$ ANDREA P. SPINA $^{3}$ \\ ${ }^{I}$ Universidad Peruana Cayetano Heredia (UPCH), Escuela Doctoral Franco-Peruana en Ciencias de la Vida. Av. Honorio Delgado \\ 430, Urb. Ingeniería, San Martín de Porres. Lima, Peru \\ E-mail: carlos.amasifuen@gmail.com \\ ${ }^{2}$ Herbier de Guyane, Institut de Recherche pour le Développement (IRD), UMR AMAP, Boite Postale 90165, 97323 Cayenne Cedex, \\ French Guiana, France \\ E-mail:piero.delprete@ird.fr \\ ${ }^{3}$ Rua Capitão Leônidas Marques 894, 81540-470 Curitiba, PR, Brazil \\ E-mail: apspina2001@yahoo.com.br \\ *Author for correspondence
}

\begin{abstract}
The delimitation of Himatanthus (Apocynaceae) species has long been problematic, and much confusion remains as to which names and species delimitations should be adopted. In order to recognize and clarify the species of Himatanthus occurring in Peru, herbarium specimens were examined, coupled with detailed field observations. The present study recognizes three species in Peru: H. revolutus, H. tarapotensis and H. phagedaenicus. A key to identify the species, as well as descriptions, synonymy, specimens cited, and taxonomic comments are presented.
\end{abstract}

Key Words: Apocynaceae, Himatanthus, Neotropics, Plumerieae, Rauvolfioideae, South America, taxonomy.

\section{Introduction}

Himatanthus Willdenow ex Roemer \& Schultes (1819: xiii; Apocynaceae) is currently recognized as a neotropical genus of nine species, characterized by alternate leaves, presence of colleters in the axils of the petiole and at the base of the floral bracts; terminal, thyrsoid inflorescences consisting of dichotomous cincinni with a reduced axis subtended by two deciduous, petaloid floral bracts, corolla infundibuliform, sinistrorsely convolute, stamens inserted near the base of corolla tube, anthers free from the style head, gynoecium hemi-syncarpous composed of two carpels, style head cylindrical or obconical with two round apices, ovary semi-inferior without nectariferous disc, two opposite, woody follicles, and seeds with a concentric wing (Spina 2004, Spina et al. 2013). Endress and Bruyn (2000) positioned Himatanthus in subfamily Rauvolfioideae (= Plumerioiodeae), tribe Plumerieae, along with nine other genera. Recently, Endress et al. (2014) confirmed the position of the genus in tribe Plumerieae, subtribe Plumeriinae, along with Plumeria Linnaeus (1753: 209) and Mortoniella Woodson (1939: 257-259). These three genera have the following common characteristics: semi-inferior ovary, style head without a basal collar, and absence of a nectariferous disk (Endress \& Bruyn 2000, Woodson 1937), and can be distinguished from each other by the characteristics cited by Woodson (1937, 1939, 1948), Plumel (1990, 1991), and Morales (2005).

Himatanthus and Plumeria have a complex, intertwined taxonomic history. For about eighteen years after its description, Himatanthus was treated as a monotypic genus with a H. rigidus Hoffmannsegg ex J.A. Schultes (1819: 221), which was described from material collected in the state of Pará, Brazil. However, Müller Argoviensis (1860) in Flora Brasiliensis, overlooked this genus and recognized only species in Plumeria.

In 1937, following the evaluation of Plumeria and Himatanthus by Woodson (1937: 189-224), the delimitation of Himatanthus was expanded to include other species, and its geographic distribution was extended from Panama throughout South America. In his study, Woodson recognized that certain species of Plumeria ranging from southern Panama to southern Brazil, are distinguishable from the other species from Central America, southern Mexico and the Antilles, by their large petaloid bracts, and he transferred the corresponding species to Himatanthus, increasing the 
number of species from one to seven. According to his treatment, four species are restricted to Brazil: H. attenuatus (Benthan 1841: 245) Woodson (1937: 197); H. lancifolius (Müller Argoviensis 1860: 41) Woodson (1937: 200); H. obovatus (Müller Argoviensis 1860: 40) Woodson (1937: 201-202); and H. phagedaenicus (Martius in Spix \& Martius 1831: 1128) Woodson (1937: 199). The other three species recognized by Woodson are distributed form southern Panama throughout southern South America: H. articulatus (Vahl 1798: 20) Woodson (1937: 196-197) occurring in Panama, Venezuela, Guyana, Surinam, French Guiana and Brazil; H. bracteatus (A. de Candolle 1844: 394) Woodson (1937: 200) in Guyana and Brazil; and H. sucuuba (Spruce ex Müller Argoviensis 1860: 40) Woodson (1937: 198-199) occurring in Bolivia, Brazil and Peru. Woodson produced a tentative key to the species of Himatanthus. However, he did not have much confidence in its reliability, and stated the following:

"Although leaf characters have been employed almost exclusively in this purely tentative treatment, it probably is inevitable that their use may have to be modified greatly as additional material, so greatly needed, finds its way into our collections. It should be borne in mind by those who attempt to use the following key that it is offered quite provisionally, and is designed merely as a basis for the re-establishment of the genus Himatanthus." (Woodson, 1937: 195)

Plumel $(1990,1991)$ distinguished Himatanthus from Plumeria by the woody branches (vs. fleshy in Plumeria), di- or tri-chasial inflorescences (vs. multi-chasial), large, enveloping, persistent bracts (vs. poorly developed, caducous), lobed calyx, with unequal, acute or lanceolate lobes, sometimes obsolete or absent (vs.with equal lobes), hypocrateriform corolla (vs. infundibuliform), thin style head [i.e., cylindrical to narrowly obconical], with a faintly developed collar (vs. globose), thin and digitate stigmas (vs. globose, separate), seeds with a circular, laterally asymmetrical wing (vs. with a terminal wing), and reticulate seed tegument (vs. plicate, rugose). He subdivided Himatanthus into two subgenera, H. subgen. Obovatae Plumel (1990: 105; 1991: $5=H$. subgen. Himatanthus) and H. subgen. Lanceolatae Plumel (1990: 105; 1991: 7). By examining type specimens Plumel $(1990,1991)$ was able to expand upon Woodson's species delineations. Consequently, he resurrected several species that Woodson previously treated as synonyms. Plumel proposed several new combinations in Himatanthus, and ultimately recognized 13 species and eight varieties in the genus. In his key to species, except for two couplets, Plumel used only leaf characters. Our research however, indicates that these leaf characters can vary within a species and sometimes even within an individual.

Subsequently, Spina (2004) performed a taxonomic revision of Himatanthus as part of an unpublished doctoral dissertation, using morphological and molecular characters. She recognized nine species and rejected the subgeneric classification proposed by Plumel (1990, 1991). She confirmed the similarities and close relationships of Himatanthus, Mortoniella and Plumeria; however, the molecular phylogenies presented in her thesis were inconclusive, as only a small number of taxa were included. Therefore, the separation and delimitation of these genera remain to be tested. Nevertheless, chromosome numbers supply significant characters in separating these closely related genera, as Williams \& Stutzman (2008) reported 2n=18 in Himatanthus, 2n=36 in Plumeria, and 2n $=32$ in Mortoniella.

Consequently, as the monophyly of Himatanthus has never been tested with molecular phylogenies, the generic delimitations proposed by Woodson (1937, 1939), Plumel (1990, 1991), Spina (2004), Spina et al. (2013), and Endress et al. (2014) are here adopted, and the species delimitations of Spina (2004) and Spina et al. (2013) are followed.

\section{Himatanthus in Peru}

To date there has been a total of six species of Himatanthus cited for Peru (Brako \& Zarucchi 1993; Ruokolainen \& Tuomisto 1998; Ulloa et al. 2004; Rodriguez et al. 2006; Tropicos, 2016): H. articulatus, H. bracteatus, H. lancifolius, H. phagedaenicus, H. sucuuba, and H. tarapotensis (K. Schumann ex Markgraf 1932: 339) Plumel (1990: 112). Our research indicates that there are fewer species in the country. The proliferation of names, in our opinion, is because a few morphological features help differentiate the species of Himatanthus and these have been variably interpreted for species delimitation and identification of herbarium specimens.

One of the most frequently reported species of Himatanthus in Peru is H. sucuuba (e.g., Macbride 1959, Acevedo 1998, Alonso et al. 1998, Vásquez 1997, Ruokolainen \& Tuomisto 1998, Vásquez \& Phillips 2000, Pitman et al. 2002, 2003 a, b, Pennington et al. 2004, Tropicos 2016). However, our study indicates that this species does not occur in the country. Rather, H. sucuuba has a complex and often misinterpreted taxonomic history with many studies in the field of ethnobotany (e.g., Bourdy et al. 2000, Shanley et al. 2011, Odonne et al. 2013), leaf anatomy (Larrosa \& Duarte 
2005), morphology (Amaro et al. 2006), biochemistry (e.g., Perdue \& Blomster 1978, Endo et al. 1994, Miranda et al. 2000, Wood et al. 2001, Silva et al. 2007, 2010), and ecology (e.g., Spichiger et al. 1990, Ferreira et al. 2007, 2009 a, b) reporting its presence in Peru. However, Spina (2004) and Spina et al. (2013) treated H. sucuuba as a synonym of Himatanthus articulatus, which is a species that does not occur in Peru. Therefore, as most of the above publications did not cite voucher specimens, it is impossible to know which species was/were actually studied. Following the species delimitations of Spina (2004) and Spina et al. (2013), we find that there are three species of Himatanthus occuring in Peru: H. phagedaenicus, H. revolutus (Huber 1915: 200) Spina \& Kinoshita (in Spina et al. 2013: 1307), and $H$. tarapotensis. For the differentiation of the three species present in Peru, most vegetative characters are of little use, taking into account the broad variation within each species (Spina 2004). For example leaf bases are cuneate, and the apices are either acute or acuminate for all species in Peru. Similarly, the number of secondary veins can vary from 12 to 24 in all Peruvian species. On the other hand, venation type and angle of the secondary veins with respect to the midrib can provide some diagnostic characters that can be used for distinguishing the species. Himatanthus revolutus has a mixed type of brochidodromus-eucamptodromus venation, whereas $H$. tarapotensis and $H$. phagedaenicus exhibit a simple brochidodromous venation. The angle of the secondary veins with respect to the midrib is useful in distinguishing $H$. revolutus, with secondary veins nearly or exactly perpendicular to the midrib $\left(80-90^{\circ}\right)$, while they are at $70-80^{\circ}$ in $H$. phagedaenicus and $50-70^{\circ}$ in H. tarapotensis.

Reproductive features are a reliable source of significant diagnostic characteristics to distinguish species of Himatanthus (Spina 2004). For example, the corollas are $45-70 \mathrm{~mm}$ long in $H$. phagedaenicus and $H$. revolutus versus $35-45 \mathrm{~mm}$ long in H. tarapotensis. Himatanthus phagedaenicus is easily distinguished by its corolla tube and lobes of approximately the same length and style head with trichomes, whereas the corolla lobes are longer than the tube and the style heads glabrous in H. tarapotensis and H. revolutus. Finally, the follicles are 27-29 cm long in H. tarapotensis, 16-26 cm long in $H$. phagedaenicus, and $12.5-25.5 \mathrm{~cm}$ long in $H$. revolutus.

\section{Material and Methods}

This study is based on examination of herbarium specimens using a dissecting microscope, digital images, direct field observations, and consultation of specialized literature. Herbarium specimens of Himatanthus were studied either by visiting and/or through loans from the following herbaria: AMAZ, B, BM, BR, C, CAY, COL, F, G, IAN, INPA, K, L, M, MBM, MG, MO, NY, P, R, RB, S, UB, USM, UEC, Z. For the species in Peru, 26 individuals from 11 localities, corresponding to various habitats, were collected. Herbarium specimens of these individuals were deposited at AMAZ, MBM and USM. Descriptions and measurements are based on herbarium specimens identified by Spina (2004), as well as 26 gatherings recently collected in Peru. The measurements reported here for vegetative, floral and fruiting characters were obtained from fresh material. Geographical distributions and ecological preferences were obtained from the information on specimen labels and field observations. Species delimitations, synonymies, geographical distributions, and specimens examined, were obtained from Spina (2004), and Spina et al. (2013), complemented by new collections and field observations.

The clarification of the species of Himatanthus in Peru has become urgent and necessary due to the many ongoing studies in the country focusing on medicinal properties, ecological preferences, and factors influencing herbivory in Himatanthus. We present the following treatment in an attempt to clarify previous taxonomic confusion of the genus in Peru.

\section{Taxonomic treatment}

Himatanthus Willdenow ex Roemer \& Schultes, Syst. Veg., ed. 15 bis, 5: XIII, 221. 1819. Type: H. rigidus Willdenow ex Roemer \& Schultes (1819: 221).

Shrubs or trees to $30 \mathrm{~m}$ tall, with white latex. Stems terete, with conspicuous leaf scars. Leaves alternate, often congested at branch tips, blades chartaceous, subcoriaceous to thickly coriaceous, margins often revolute; secondary veins joined by a series of marginal loops. Inflorescences terminal or pseudo-lateral by reiteration of axillary buds, cymose or thyrsiform, multiflorous; bracts large, showy, caducous, with numerous glands at base. Flowers 5-merous. Calyx small, persistent, lobes small, unequal, imbricate. Corolla hypocrateriform, large, white; tube narrow, straight, 
glabrous inside; lobes convoluted in bud, spreading or reflexed at anthesis. Stamens inserted at the lower portion of the corolla tube; anthers subsessile, lanceolate, basally sagittate. Ovary apocarpous, topped by a fusiform or cylindrical stigmatic head; ovules numerous in each locule. Fruit consisting of two separate, banana-like follicles, straight or curved, drying at maturity, dehiscing by a ventral slit. Seeds dry, compressed, with a papery, concentric wing.

Geographic distribution: Himatanthus has nine species widespread throughout South America, one of them ( $H$. articulatus) extending to Panama.

\section{Key to the species of Himatanthus occurring in Peru}

1 Leaf venation brochidodromous-eucamptodromus; secondary veins at $80-90^{\circ}$ angle with the midrib .................... 2. H. revolutus

1 Leaf venation brochidodromous; secondary veins at $50-80^{\circ}$ angle with the midrib ......................................................................2

2 Secondary veins at 50-70 angle with the midrib; corolla tube 15-20 mm long, lobes $20-25 \mathrm{~mm}$ long; style head glabrous; follicles

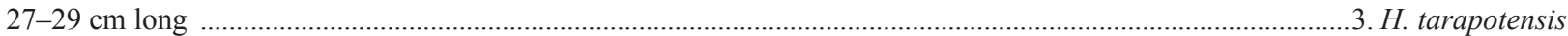

2 Secondary veins at $70-80^{\circ}$ angle with the midrib; corolla tube $20-35 \mathrm{~mm}$ long, lobes $25-35 \mathrm{~mm}$ long; style head pubescent; follicles $16-26 \mathrm{~cm}$ long .................................................................................................................... 1. H. phagedaenicus

1. Himatanthus phagedaenicus (Martius) Woodson, Ann. Missouri Bot. Gard. 25: 199. 1937 [“1938”] (as "phagedaenica"). Plumeria phagedaenica Martius in Spix \& Martius, Reise Bras. 3: 1128. 1831.

Type:-BRAZIL. Amazonas: Manaus, Cachoeira, prope Barra do Rio Negro [now Manaus], s.d., C.F.P. Martius 2778 (first-step lectotype, designated by Plumel (1991: 65); second step-lectotype, here designated: M [barcode M-0183348], photos at F, INPA, MO, RB).

Small or medium-size trees, $2-15 \mathrm{~m}$ tall; young stems dark brown with bright brown spots, older stems grayish; periderm smooth in young stems, striate in older stems. Leaves with petioles 20-35(-45) mm long, glabrous; blades obovate, oblanceolate or elliptic, 15-23(-27.5) x 7-9.5(-11) cm, coriaceous, base cuneate, apex acute, obtuse-emarginate or round, sometimes short-acuminate, margin revolute; venation brochidodromous; secondary veins at $70-80^{\circ}$ angle, 14-23 on each side of midrib; tertiary veins slightly evident on both sides. Bracts $20-30 \mathrm{~mm}$ long, glabrous. Calyx 4-8 $\times 2 \mathrm{~mm}$; lobes ovate, $0.5-1(-1.5) \mathrm{mm}$ long, unequal in size, with 3 or all reduced. Corolla $45-70 \mathrm{~mm}$ long; tube $25-35$ × 2-3 mm, pilose inside at distal 6-10 mm of corolla tube; lobes elliptic, $25-35$ x 8-12 mm. Stamens $2.5 \mathrm{~mm}$ long, inserted at 2-2.5 mm from the base of corolla tube. Style head obconical, pubescent, without protuberance, 2.0 $\mathrm{mm}$ long, with 2 short apices $0.2-0.5 \mathrm{~mm}$ long. Follicles $16-26 \times 2-3 \mathrm{~cm}$; pericarp striate with two lateral prominent ribs, yellowish. Seeds 50 x 25-40 mm, with apical wing larger than basal and lateral wings; seminal nucleus $25-30 \times$ $10 \mathrm{~mm}$; hilum $10 \mathrm{~mm}$ long.

Distribution:-From Venezuela, Guyana, Suriname, and French Guiana to Amazonian Colombia, Peru and Brazil.

Taxonomic notes:-Martius (in Spix \& Martius 1831), when he described Plumeria phagedaenica Martius (in Spix \& Martius 1831: 1128) did not cite any collection number or herbarium of deposit. Müller Argoviensis (1860: 40, tab. 11, fig. 1) cited the same gathering indicated by Martius, also without collection number or herbarium of deposit. Woodson (1937: 199) cited the type of this name as: "Brazil: Amazonas: sylvis ad Rio Cachoeira prope Barra do Rio Negro, Oct., year lacking, Martius 2778 (M, type)." Plumel (1991: 65) cited the type as "Martius 2778, Manaus, holo-M" which is a first-step lectotypification. There are two specimens of this taxon collected by Martius at M, and only one, with barcode M-0183348, has Martius' collection number " 2778 ", which is here selected as a second-step lectotype.

Selected specimens examined:-PERU. Loreto: Between Quistococha and Santo Tomas, $14 \mathrm{~km}$ from Iquitos, 18 August 1981 (fl), Moore et al. [additional collectors unknown] 123 (F); Prov. Maynas, across lake Quistococha, opposite Fish Experiment Station, W of Iquitos, 17 November 1975 (fl), C. Davidson 3567 (MO, NY); Dtto. Alto Nanay, Río Nanay, Quebrada Anguilla, upland never inundated, 29 March 1978 (fr), M.Y. Rimachi 3494 (F, MO); Prov. Requena, Quebrada Yanayacu-Río Tapiche, 19 October 2014 (fl), M. Ríos, T. Mori, N. Pitman, L. Torres \& C. Vriesendorp 4553 (F, USM, MBM).

2. Himatanthus revolutus (Huber) Spina \& Kinoshita, Taxon 62: 1307. 2013. $\equiv$ Plumeria revoluta Huber (as "Plumiera"), Bull. Soc. Bot. Genève, ser. 2, 6: 200. 1915. झHimatanthus bracteatus var. revolutus (Huber) Plumel, Compt. Rend. Séances Soc. Biogéogr. 66(3): 114. 1990. 
Type:-BRAZIL. Amazonas: Região do Alto Ariramba [Campos de Ariramba], campinarana, 21 December 1906, A. Ducke s.n. (MG 8039) (lectotype, here designated: G [barcode G00164788], photos at INPA, MO, NY; not at MG).

Himatanthus stenophyllus Plumel, Compt. Rend. Séances Soc. Biogéogr. 66(3): 116. 1990.

Type:-BRAZIL. Amazonas: Mun. Manaus, estrada Manaus-Itacoatiara, km 28, 6 December 1983, M.M. Plumel \& D.F. Coêlho 8391 (holotype P [barcode P00076082]; isotype INPA [barcode INPA112835]).

Small or medium-size trees, 3-12 m tall; young stems dark brown, older stems brown; periderm smooth in young stems, rugose, striate in older stems. Leaves with petioles 15-20 mm long, glabrous; blades oblanceolate, 10.5-18.5(-20) x 3$5 \mathrm{~cm}$, base cuneate, apex acute to obtuse, margin revolute, chartaceous; venation brochidodromous-eucamptodromous; secondary veins at $80-90^{\circ}$ angle, $(8-) 13-17(-23)$ on each side of midrib; tertiary veins slightly evident in both sides. Bracts 20-25 mm long. Calyx 5-7 x $2 \mathrm{~mm}$; lobes ovate, 0.1-1(-2.5) $\mathrm{mm}$ long, unequal in size, 1, 4 or all reduced. Corolla $45-70 \mathrm{~mm}$ long; tube $20-30 \times 2-3 \mathrm{~mm}$, pilose inside at distal $1 / 2$ of corolla tube; lobes obovate, $25-40 \times 5-8$ $\mathrm{mm}$. Stamens $2.5 \mathrm{~mm}$ long, inserted at $1.5-2 \mathrm{~mm}$ from base of corolla tube. Style head obconical, 1.5-2 mm long, glabrous, with 5 striations, with 2 apices $0.2 \mathrm{~mm}$ long, flat. Follicles $12.5-25.5 \times 3 \mathrm{~cm}$; pericarp striate with two lateral prominent ribs, dark brown. Seeds $30-50$ x $25-30 \mathrm{~mm}$, with apical, basal and lateral wings of the same size; seminal nucleus 30-50 x 25-30 mm; hilum $15 \mathrm{~mm}$ long.

Distribution:-From Venezuela, Guyana, Suriname, French Guiana, to Amazonian Colombia, Peru and Brazil.

Taxonomic notes:- This species has not been previously reported from Peru in any of the literature cited above. The identification of this species was recently made, from a new record collected in the Loreto District.

Huber (1915) described Plumeria revoluta Huber (1915: 200) and cited the gathering "Hab. in regione fl. Arirambae superioris in fruticetis "Campina rana" dictis, 21 décembre 1906, leg. A. Ducke (8039)." However, he did not indicate this collection as type and did not cite the herbarium of deposit. In addition, "8039" is not a collection number, but is the accession number of this specimen of the Museu Goeldi (MG), because at that time Ducke did not use collection numbers; therefore, this gathering should be cited as "A. Ducke s.n. (MG 8039)."

Plumel (1990: 114-116) reduced Plumeria revoluta to a variety of Himatanthus bracteatus (A. de Candolle 1844: 394) Woodson (1937: 200), and cited the type as "Ducke A. 11358, MG BM" without any explanation. This citation is a first-step neotypification, because he cited MG and BM herbaria. A year later, Plumel (1991: 79) explained that, because he was unable to find Ducke s.n. (MG 8039), he designated a neotype. The neotype was cited as "Ducke 11399 RB, $S^{m}$ de Paranaquara, Brésil, Néo- RB, Syn- U.” Plumel's (1991: 79) citation of Ducke 11399 at RB was not a valid neotypification because he had already neotypified the name on Ducke 11358 in his previous publication (Plumel 1990).

Recently, Spina et al. (2013) found a specimen of Ducke s.n. (MG 8039) at G, citing it as "Holotype: [...], Ducke s.n. (G! photos: INPA!, MO!, NY!)." Their citation as holotype is incorrect, as Huber (1915: 200) did not cite the herbarium of deposit. It cannot be recognized as a lectotypification because, according to the International Code of Nomenclature for algae, fungi, and plants (ICNafp), it must now state "here designated" (or equivalent) to be valid. In addition, as Spina et al. (2013) had found a specimen of Ducke s.n. (MG 8039), according to Art. 9.19 of the ICNafp (McNeill et al. 2012) Plumel's (1990) neotypification on Ducke 11358 is superseded. Also, after an exhaustive search of Ducke s.n. (MG 8039) at MG, we are convinced that it is lost. Therefore, we here designate Ducke s.n. (MG 8039) at G, barcode G00164788, as the lectotype of Plumeria revoluta.

Specimen examined:-PERU: Loreto: Dtto. San Juan, Localidad de Quistococha, km 4.5 en la carretera IquitosNauta, 23 September 2015 (fl), N. Mitidieri \& U. Mozombite 16 (USM).

3. Himatanthus tarapotensis (K. Schumann ex Markgraf) Plumel, Compt. Rend. Séances Soc. Biogéogr. 66(3): 112. 1990. $\equiv$ Plumeria tarapotensis K. Schumann ex Markgraf, Notizbl. Bot. Gart. Berlin-Dahlem 11: 339. 1932.

Type:-PERU. Loreto, Tarapoto, October 1902, E. Ule 6473 (B destroyed; lectotype designated by Spina et al. (2013: 1307): G [barcode G00164786]; isolectotype MG [barcode MG006333]).

Small or medium-size trees, 7-15 m tall; young stems dark brown with yellowish spots, older stems deep brown; periderm smooth in young stems, flaky in older stems. Leaves with petioles $15-35 \mathrm{~mm}$ long, glabrous; blades narrowly elliptic, (16-)18-26(-29) x 4-6(-7) cm, base cuneate to decurrent, apex acute or acuminate, chartaceous, margin slightly revolute or undulate; venation brochidodromous; secondary veins at 50-70 angle, (11-)14-20 on each side of 
midrib; tertiary veins emergent on adaxial side, immersed in the lamina and darker than lamina on abaxial side. Bracts 15-20(-25) mm long. Calyx 5-10 × $2 \mathrm{~mm}$; lobes ovate, 0.1-0.5(-0.6-1) $\mathrm{mm}$ long, unequal in size, 3 or all reduced. Corolla 35-45 mm long; tube 15-20 × $2 \mathrm{~mm}$, throat pilose at distal 1/3 of corolla tube, lobes obovate, 20-25 x 4-6 $\mathrm{mm}$. Stamens 2-2.5 mm long, inserted at 1.5-2 mm from the base of corolla tube. Style head obconical, $1.5 \mathrm{~mm}$ long, glabrous, without protuberances, with 2 apices $0.5 \mathrm{~mm}$ long. Follicles $27-29 \times 3.5-4.5 \mathrm{~cm}$; pericarp striate, with two lateral prominent ribs, brown. Seeds $60 \times 35 \mathrm{~mm}$, with apical and basal wings smaller than lateral wings; seminal nucleus 35 x $10 \mathrm{~mm}$; hilum $15 \mathrm{~mm}$ long.

Distribution:-From Colombia, Venezuela, and French Guiana to Amazonian Ecuador, Peru, Brazil and Bolivia.

Selected specimens examined:-PERU. Amazonas: Prov. Bagua, Quebrada Tambillo (opposite kms 280-282 of Marañón road), valley of Río Marañón, above Cascadas de Mayasi, 18 September 1962 (fl), J.J. Wurdack 2048 (F, MO, NY, S). Huánuco: Dtto. Puerto Inca, Bosque Nacional de Iparia, a lo largo del Río Pachitea, 23 December 1968 (fl), J.V. Schunke 2916 (G, NY); Prov. Leoncio Prado, localidad Rupa-Rupa, 25 October 2014 (fl) R. Zárate, M. Sosa, E. Rengifo, R. Remusgo, S. Filomeno \& M. Mori 20197 (MBM). Junín: La Merced, Río Seco, 1944 (fl), J.J. Soukup 2496 (F); 10-24 August 1923 (st), J.F. MacBride 5402 (F). Loreto: Reserva Nacional Allpahuayo-Mishana, 12 March 2014 (fl), C.A. Amasifuen \& R. Pua 3483 (AMAZ, USM), 3484 (MBM, USM), 3485 (MBM), 3486 (MBM), 3487 (AMAZ, MBM); Cerro Escalera, 30 July 2013 (fl), T. Mori 1961, 1962, 1963 (MBM); Comunidad Tangarana, Río Atacuari, 5 February 2014 (fl), C.A. Amasifuen, T. Mori, M. Panaifo \& G. Panaifo 3478 (AMAZ, MBM, USM); localidad Jenaro Herrera, quebrada Supay, 21 July 2014 (fl), C.A. Amasifuen, N. Villacorta \& N. Macedo 3488 (AMAZ, MBM, USM); localidad Bagazán, quebrada Carahuayte, 24 July 2014 (fl), C.A. Amasifuen, A. Vásquez \& N. Macedo 3489 (AMAZ, MBM, USM); localidad Pebas, comunidad Pucaurquillo, 28 September 2014 (fl), R. Zárate, D. Fagua \& A. García 20153 (MBM); comunidad Santa Lucía de Pro, 30 September 2014 (fl), R. Zárate, D. Fagua \& P. Gonzales 20181 (MBM).

\section{Acknowledgments}

This study is part of a doctoral dissertation of the first author, developed at the Escuela Doctoral Franco Peruana en Ciencias de la Vida, Universidad Peruana Cayetano Heredia and École Doctorale GAIA Biodiversité, Agriculture, Alimentation, Environnement, Terre, Eau, Université de Montpellier, France. We thank the directors and curators of the herbaria listed in the Material \& Methods for loan of material, providing digital images, and for providing working space during our visits. This project was supported by a Franco-Peruvian doctoral fellowship from the National Council for Science, Technology and Technological Innovation (Consejo Nacional de Ciencia, Tecnología e Innovación Tecnológica, CONCYTEC) of the Peruvian Government, and the French Embassy in Peru. The Institut de Recherche pour le Developpement (IRD) also supported this project by sponsoring field work in Peru through the Laboratorio Mixto Internacional Andino Amazónico en Química de la Vida led by Michel Sauvain, travel expenses to the Herbier de Guyane (CAY), Cayenne and field work in French Guiana by the first author. The Research Institute of the Peruvian Amazon (Instituto de Investigaciones de la Amazonía Peruana, IIAP) allowed us to carry out part of the fieldwork at its biological station within the Allpahuayo Mishana National Reserve. Permission to study and collect in the Peruvian Amazon were granted by the Servicio Nacional Forestal y de Fauna Silvestre (SERFOR) and the Servicio Nacional de Areas Naturales Protegidas (SERNANP) of Peru. Nicole Mitidieri, Ricardo Zárate and Tony Mori collected and donated part of the specimens included in this study. Marcos Ríos also contributed fertile specimens as part of Project IRB 27 (Inventario Rápido Biológico) Tapiche-Blanco of the Río Tapiche, a remote area of the Peruvian Amazon. We would like to thank Joseph Kirkbride (Smithsonian Institution, Washington, USA), John Wiersema (U.S. National Arboretum, USDA-ARS, Beltsville, USA), Mary Endress (Zurich University, Switzerland), Michael Nee (Missouri Botanical Garden, St. Louis, USA), and the anonymous reviewers for valuable comments and corrections to the manuscript.

\section{References}

Acevedo, P. (1998) Flora II: biodiversity assessment along the Camisea and Urubamba Rivers in the lower Urubamba region. In: Alonso, A. \& Dallmeier, F. (Eds.) Biodiversity assessment and monitoring of the lower Urubamba Region, Peru. SI/MAB. Serie 2. Smithsonian 
Institution/MAB Biodiversity Program, Washington, pp. 57-62.

Alonso, A., Dallmeieri, F., Mistry, S., Ros, C., Udvardy, S. \& Comiskey, J. (1998) Flora I: biodiversity assessment in the lower Urabamba region. In: Alonso, A. \& Dallmeier, F. (Eds.) Biodiversity assessment and monitoring of the lower Urubamba region, Peru. SI/MAB. Serie 2. Smithsonian Institution/MAB Biodiversity Program, Washington, pp. 33-46.

Amaro, M.S., Filho, S.M., Guimarães, R.M. \& Teófilo, E.M. (2006) Morfologia de frutos, sementes e de plântulas de janaguba (Himatanthus drasticus (Mart.) Plumel. - Apocynaceae). Revista Brasileira de Sementes 28: 63-71.

http://dx.doi.org/10.1590/S0101-31222006000100009

Benthan, G. (1841) Contributions towards a Flora of South America - Enumerations of plants collected by Mr. Schomburgk in British Guiana. Journal of Botany 3: 212-250.

Bourdy, G., DeWalt, S.J., Chávez de Michel, L.R., Roca, A., Deharo, E., Muñoz, V., Balderrama, L., Quenevo, C. \& Gimenez, A. (2000) Medicinal plants uses of the Tacana, an Amazonian Bolivian ethnic group. Journal of Ethnopharmacology 70: 87-109. http://dx.doi.org/10.1016/S0378-8741(99)00158-0

Brako, L. \& Zarucchi, J.L. (1993) Catalogue of the flowering plants and gymnosperms of Peru. Monographs in Systematic Botany from the Missouri Botanical Garden 45: xi +1286 pp.

Candolle, A. de (1844) Plumeria bracteata. In: Candolle, A. de (Ed.) Prodromus Systematis Naturalis Regni Vegetabilis. Volume 8. Fortin, Masson \& Soc., Paris, 394 pp.

Encarnación, F. (1993) El bosque y las formaciones vegetales en la llanura amazónica del Perú. Alma Mater 6: 93-114.

Endo, Y., Hayashi, H., Sato, T., Maruno, M., Ohta, T. \& Nozoe, S. (1994) Confluentic acid 2'-0-methylperlatolic acid, monoamine oxidase b inhibitors in a Brazilian plant, Himatanthus sucuuba. Chemical and Pharmaceutical Bulletin 42: 1198-1201. http://dx.doi.org/10.1248/cpb.42.1198

Endress, M.E. \& Bruyn, P.V. (2000). A revised classification of the Apocynaceae s.1. The Botanical Review 66: 1-56. http://dx.doi.org/10.1007/BF02857781

Endress, M.E., Liede-Schumann, S. \& Meve, U. (2014) An updated classification for Apocynaceae. Phytotaxa 159 (3): $175-194$. http://dx.doi.org/10.11646/phytotaxa.159.3.2

Ferreira, C.S., Piedade, M.T.F., Junk, W.J. \& Parolin, P. (2007) Floodplain and upland populations of Amazonian Himatanthus sucuuba: effects of flooding on germination, seedling growth and mortality. Environmental and Experimental Botany 60: 477-483. http://dx.doi.org/10.1016/j.envexpbot.2007.01.005

Ferreira, C.S., Piedade, M.T.F., Franco, A.C., Gonçalves, J.F.C. \& Junk, W.J. (2009a) Adaptive strategies to tolerate prolonged flooding in seedlings of floodplain and upland populations of Himatanthus sucuuba, a Central Amazon tree. Aquatic Botany 90: $246-252$. http://dx.doi.org/10.1016/j.aquabot.2008.10.006

Ferreira, C.S., Piedade, M.T.F., Tiné, M.A.S., Rossatto, D.R., Parolin, P. \& Buckeridge, M.S. (2009b) The role of carbohydrates in seed germination and seedling establishment of Himatanthus sucuuba, an Amazonian tree with populations adapted to flooded and nonflooded conditions. Annals of Botany 104: 1111-1119.

http://dx.doi.org/10.1093/aob/mcp212

Huber, J. (1915) Plantae Duckeanae austro-guyanenses. Bulletin de la Societé Botanique de Genève, ser. 2 6: $179-212$.

Josse, C., Navarro, G., Encarnación, F., Tovar, A., Comer, P., Ferreira, W., Rodríguez, F., Saito, J., Sanjurjo, J., Dyson, J., Rubin de Celis, E., Zárate, R., Chang, J., Ahuite, M., Vargas, C., Paredes, F., Castro, W., Maco, J. \& Reátegui, F. (2007) Sistemas ecológicos de la cuenca Amazónica de Perú y Bolivia. Clasificación y mapeo. Nature Serve. Arlington, Virginia, USA. 94 pp.

Larrosa, C.R.R. \& Duarte, M.R. (2005) Morfoanatomia de folhas de Himatanthus sucuuba (Spruce) Woodson, Apocynaceae. Acta Farmacéutica Bonaerense 24: 165-171.

Linnaeus, C. (1753) Species plantarum. Volume 1. Imprensis Laurentii Salvii, Holmiae [Stockholm], 560 pp.

Linnaeus, C. f. (“1781” [1782]) Mauritia flexuosa. Supplementum Plantarum. Impensis Orphanotrophei, Brunsvigae, 454 pp.

Macbride, J.F. (1959) Apocynaceae. Flora of Peru. Publications of the Field Museum of Natural History, Botanical Series 13 (5/1): $363-455$.

Malleux, J. (1975) Mapa forestal del Perú (memoria explicativa). Departamento de Manejo Forestal, Universidad Nacional Agraria La Molina, Lima, Perú, 161 pp.

Markgraf, F. (1932) Apocynaceae. In: Pilger, Plantae Luetzelburgianae. Notizblatt des Botanischen Gartens und Museums zu BerlinDahlem 11: 312-429.

McNeill, J., Barrie, F.R., Buck, W.R., Demoulin, V., Greuter, W., Hawksworth, D.L., Herendeen, P.S., Knapp, S., Marhold, K., Prado, J., Prud'homme van Reine, W.F., Smith, G.F., Wiersema, J.H. \& Turland, N.J. (Eds.) (2012) International Code of Nomenclature for algae, fungi, and plants (Melbourne Code). Regnum Vegetabile. Volume 154. Königstein: Koeltz Scientific Books. Available from: http://www.iapt-taxon.org/nomen/main.php (accessed 1 November 2016)

Miranda, A.L.P., Silva, J.R.A., Rezende, C.M., Neves, J.S., Parrini, S.C., Pinheiro, M.L.B., Cordeiro, M.C., Tamborini, E. \& Pinto, A.C. (2000) Anti-inflammatory and analgesic activities of the latex containing triterpenes from Himatanthus sucuuba. Planta Medica 66: 
284-286.

http://dx.doi.org/10.1055/s-2000-8572

Morales, J.F. (2005) Estudios en las Apocynaceae neotropicales XIX: la familia Apocynaceae s. str. (Apocynoideae, Rauvolfioideae) de Costa Rica. Darwiniana 43: 90-191.

Müller Argoviensis, J. (1860). Apocynaceae. In: Martius, C.F.P. (Ed.) Flora Brasiliensis. Volume 6, part 1. F. Fleischer, Munich, pp. 1-196, pl. 11-12.

Odonne, G., Valadeau, C., Alban-Castillo, J., Stien, D., Sauvain, M. \& Bourdy, G. (2013) Medical ethnobotany of the Chayahuita of the Paranapura basin (Peruvian Amazon). Journal of Ethnopharmacology 146: 127-153.

http://dx.doi.org/10.1016/j.jep.2012.12.014

Perdue, G.P. \& Blomster, R.N. (1978) South American plants III: isolation of fulvoplumierin from Himatanthus sucuuba (M. Arg.) Woodson (Apocynaceae). Journal of Pharmaceutical Sciences 67: 1322-1323. http://dx.doi.org/10.1002/jps.2600670936

Pennington, T.D., Reynel, C. \& Daza, A. (2004) Illustrated Guide to the Trees of Peru. Published by David Hunt, Milborne Port, Sherborne, England, $848 \mathrm{pp}$.

Pitman, N.C.A., Terborgh, J.W., Silman, M.R., Nuñez, P., Neill, D.A., Cerón, C.E., Palacios, W.A. \& Aulestia, M. (2002) A comparison of tree species diversity in two upper Amazonian forests. Ecology 83: 3210-3224.

http://dx.doi.org/10.1890/0012-9658(2002)083[3210:ACOTSD]2.0.CO;2

Pitman, N.C.A., Beltran, H., Foster, R., García, R., Vriesendorp, C. \& Ahuite, M. (2003a). Flora y vegetación. In: Pitman, N., Vriesendorp, C. \& Moskovits, D. (Eds.) Peru: Yavarí. Rapid biological inventories Report 11. The Field Museum, Chicago, pp. 52-59.

Pitman, N.C.A., Terborgh, J., Núñez, M.P. \& Valenzuela, M. (2003b) Los árboles de la cuenca del río Alto Purús. In: Leite Pitman, M.R.P., Pitman, N.C.A. \& Alvarez, P. (Eds.), Alto Purús: biodiversidad, conservación y manejo. Impresso Gráfica S.A., Lima, pp. 53-62.

Plumel, M.M. (1990) Repartition geographique du genre Himatanthus en Amerique tropicale. Compte Rendu des Séances de la Société de Biogeographie. Paris 66: 103-127.

Plumel, M.M. (1991) Le genre Himatanthus (Apocynaceae) révision taxonomique. Bradea 5 (suppl.): 1-118.

Rodriguez, E., Vásquez, R., Rojas, R., Calatayud, G., León, B. \& Campos, J. (2006) Nuevas adiciones de angiospermas a la flora del Perú. Revista Peruana de Biología 13: 129-138.

http://dx.doi.org/10.15381/rpb.v13i1.1776

Roemer, J.J. \& Schultes, J.A. (1819) Systema Vegetabilium, Ed. 15 bis. Volume 5. Sumtibus J.G. Cottae, Stuttgart, lii+632 pp.

Ruokolainen, K. \& Tuomisto, H. (1998) Vegetación natural de la zona de Iquitos. In: Kalliola, R. \& Paitan, S.F. (Eds.) Geoecología y desarrollo Amazónico: estudio integrado en la zona de Iquitos, Perú. University of Turku Press, Finland, pp. $253-368$.

Shanley, P., Cymerys, M., Serra, M. \& Medina, G. (Eds.) (2011) Fruit trees and useful plants in Amazonian life. Food and Agriculture Organization of the United Nations. Brazil, xxiv +353 pp.

Silva, J.R.A., Amaral, A.C.F., Silveira, C.V., Rezende, C.M. \& Pinto, A.C. (2007) Quantitative determination by HPLC of iridoids in the bark and latex of Himatanthus sucuuba. Acta Amazonica 37: 119-122.

http://dx.doi.org/10.1590/S0044-59672007000100014

Silva, J.R.A., Rezende, C.M., Pinto, A.C. \& Amaral, A.C.F. (2010) Cytotoxicity and antibacterial studies of iridoids and phenolic compounds isolated from the latex of Himatanthus sucuuba. African Journal of Biotechnology 9: 7357-7360.

Spichiger, R., Méroz, J., Loizeau, P.-A. \& Stutz, L. (1990) Los árboles del arborétum Jenaro Herrera, vol. II, Linaceae a Palmae. Boissiera 44: $1-563$.

Spina, A.P. (2004) Estudos taxonômico, micro-morfológico e filogenético do gênero Himatanthus Willd. ex Schult. (Apocynaceae: Rauvolfioideae - Plumerieae). Doctoral Dissertation, Universidade Estadual de Campinas, Campinas, SP, Brazil. vi+191 pp.

Spina, A.P., Bittrich, V. \& Kinoshita, L.S. (2013) Typifications, new synonyms and a new combination in Himatanthus (Apocynaceae). Taxon 62: 1304-1307.

http://dx.doi.org/10.12705/626.16

Spix, J.B. \& Martius, C.F.P. (1831) Reise in Brasilien. Volume 3. Gedruckt bei dem Verfasser Leipzig, in Comm. bei Friedr. Fleischer, Munchen, pp. [i]-lvi, [1]-40, [885]-1388.

Tropicos (2016) Botanical information system at the Missouri Botanical Garden. Available from: http://www.tropicos.org/ (accessed 14 February 2016)

Ulloa, C., Zarucchi, J. \& León, B. (2004) Diez años de adiciones a la Flora del Perú: 1993-2003. Arnaldoa edición especial, 242 pp.

Vahl, M. (1798) Eclogce Americance. Vol. 2. Impensis auctoris, Hauniae [Copenhagen], 56 pp.

Vásquez, R. (1997) Flórula de las Reservas Biológicas de Iquitos, Perú. The Missouri Botanical Garden Press, St. Louis, MO, USA, xiii+2021 pp.

Vásquez, R. \& Phillips, O. (2000) Allpahuayo: floristics, structure, and dynamics of a high-diversity forest in Amazonian Perú. Annals of the Missouri Botanical Garden 87: 499-527. 
http://dx.doi.org/10.2307/2666143

Williams, J.K. \& Stutzman, J.K. (2008) Chromosome number of Thevetia ahouai (Apocynaceae: Rauvolfioideae: Plumerieae) with discussion on the generic boundaries of Thevetia. Journal of the Botanical Research Institute of Texas 1: 489-493.

Wood, C.A., Lee, K., Vaisberg, A.J., Kingston, D.G.I., Neto, C.C. \& Hammond, G.B. (2001) A bioactive spirolactone iridoid and triterpenoids from Himatanthus sucuuba. Chemical and Pharmaceutical Bulletin 49: 1477-1478. http://dx.doi.org/10.1248/cpb.49.1477

Woodson, R.E. (1937 [“1938”]) Studies in the Apocynaceae. VII - An evaluation of the genera Plumeria L. and Himatanthus Willd. Annals of the Missouri Botanical Garden 25: 189-224. http://dx.doi.org/10.2307/2394479

Woodson, R.E. (1939) New or otherwise noteworthy Apocynaceae of Tropical America. VII. Annals of the Missouri Botanical Garden 26: 257-259. http://dx.doi.org/10.2307/2394294

Woodson, R.E. (1948) Miscellaneous new Apocynaceae and Asclepiadaceae. Annals of the Missouri Botanical Garden 35: $233-238$. http://dx.doi.org/10.2307/2394532 